\title{
Description of Pythonella scleruri n. sp. (Apicomplexa: Eimeriidae) from a Brazilian Bird Rufous-Breasted- Leaftosser Sclerurus scansor, 1835 (Passeriformes: Furnariidae)
}

\author{
Urara Kawazoe/ ${ }^{+}$, Hélio Gouvêa* \\ Departamento de Parasitologia, Instituto de Biologia, Unicamp, Caixa Postal 6.109, 13083-970 Campinas, SP, \\ Brasil *Associação Pró-Parque Nacional do Itatiaia, Av. Roberto Silveira 5, Itatiaia, RJ, Brasil
}

Coccidian oocysts containing 16 sporocysts with 4 sporozoites in each were observed in a faecal sample from Sclerurus scansor collected in the Itatiaia National Park, southeastern region of Brazil. The oocysts are characterized by ellipsoidal shape measuring $42.5 \times 32.8 \mathrm{~mm}$, with smooth, thick doublelayered wall of a greenish-orange colour. An oocyst residuum of numerous scattered granules among the sporocysts in sporulated ones; 16 round sporocysts, averaging $10.5 \times 10 \mathrm{~mm}$ each containing four elongated sporozoites; presence of residuum; absence of Stieda body. The presently described coccidian, recorded for the first time in birds, is a new species named $\mathrm{P}$. scleruri.

Key words: Pythonella scleruri - new species - wild bird - Sclerurus scansor - Brazil

A survey of intestinal coccidiosis from 29 wild birds belonging to 14 different species was conducted in the Itatiaia National Park, southeastern region of Brazil. Isospora spp. oocysts were detected in 12 of those birds and oocysts containing 16 sporocysts, each containing 4 sporozoites were also observed in a faecal sample from a RufousBreasted-Leaftosser Sclerurus scansor. All the species of birds examined were from the Order Passeriformes.

Oocysts with 16 sporocysts, each with 4 sporozoites have been previously described as Pythonella bengalensis from the snake Python sp., in India, by Ray and Das-Gupta (1937). Later, Duszynski (1969) described P. scelopori from a Costa Rican lizard Sceloporus aquamosus.

Hundreds of similar sporulated oocysts with 16 sporocysts and 4 sporozoites in each were observed in a faecal sample of Rufous-Breasted-Leaftosser S. scansor, Family Furnariidae, from Itatiaia National Park.

\section{MATERIALS AND METHODS}

Birds were trapped by using bird trap nets, banded, identified, and then released. Each bird was kept for about $15 \mathrm{~min}$ in a small cotton bag, time enough for a faecal specimen. The faecal

\footnotetext{
${ }^{+}$Corresponding author. Fax: +55-19-289.3124. E-mail: urka@correionet.com.br

Received 16 June 1998

Accepted 13 January 1999
}

samples were separately kept in $2 \%$ potassium dichromate solution for at least one week to allow oocyst sporulation. Fifty sporulated oocysts and 60 sporocysts were measured by a calibrated micrometer (Carl Zeiss).

\section{DESCRIPTION}

\section{Pythonella scleruri n. sp.}

Morphology: sporulated oocysts were characterized by their broadly ellipsoidal shape with a smooth, double-layered, thick wall $(1.8 \mathrm{~mm})$, greenish-orange colour, with a residuum of numerous scattered granules in sporulated oocysts. Micropyle absent. Oocysts average 42.5 by $32.8 \mathrm{~mm}$ ( 35 to 49.1 by 28.9 to 37.6 ) with a shape index of 1.27 (1.05 to 1.45). Round sporocysts, each containing four elongated sporozoites and a residuum; no Stieda body; sporocysts average 10.5 by 10 ( 9.5 to 12.5 by 8.7 to 12$) \mathrm{mm}$ with shape index of 1.09 (1.01 to 1.16). Fig. 1 is a line drawing of a mature oocyst containing 16 sporocysts; Fig. 2A shows an oocyst with 10 sporocysts and the residuum of scattered granules in focus; Fig. 2B shows an oocyst with 7 sporocysts with visible sporozoites in 3 of them; Fig. 2C shows an oocyst with one sporocyst containing 4 sporozoites and another one with 2 sporozoites in focus; in Fig. 2D the oocyst contains 10 visible sporocysts with at least 3 sporozoites in some of them and the residuum with scattered granules, in focus whereas in Fig. 2E the oocyst with 6 sporocysts in focus shows 2 or 3 visible sporozoites in some of them with the residuum of scattered granules among the sporocysts. 


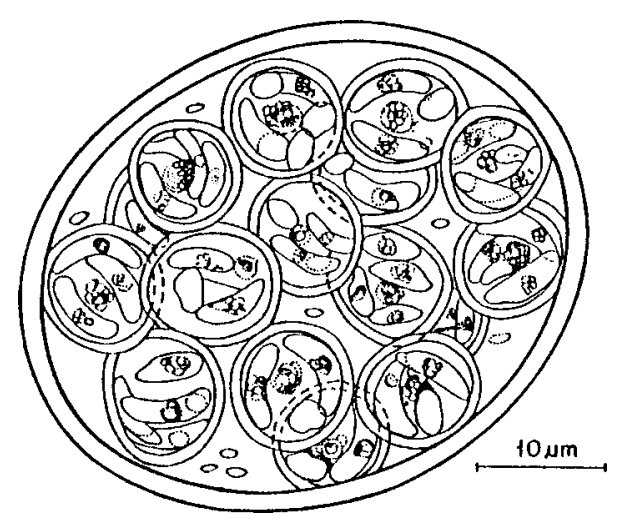

Fig. 1: sporulated oocyst of Phythonella scleruri n. sp. from Sclerurus scansor (drawing).

Type host: Sclerurus scansor "Rufous-BreastedLeaftosser", Family Furnariidae.

Type location in the host: unknown; oocysts found in a faecal sample.

Sporulation time: unkown. Oocysts were stored in $2 \%$ potassium dichromate for about one week before examination.

Type locality: National Park of Itatiaia (Itamonte), Minas Gerais, Brazil. Altitude: 1,600 m.

Prevalence: only one of two specimens trapped (50\%) was passing oocysts.

\section{REMARKS}

P. bengalensis is the type species of the genus Pythonella characterized by heccaidesporocystid oocysts and tetrazoic sporocysts (Pellérdy 1974) first described by Ray and Das-Gupta in 1937, from a snake. They gave only the diameter of oocysts (25 to $30 \mathrm{~mm}$ ), length and width of sporocysts (8 to 10 by $6.7 \mathrm{~mm}$ ) with limited information on macrogametes found in the submucosa. Oocysts eliminated with faeces undergo sporulation in 7 to 10 days, although sporulation may start within the intestinal epithelium of the host. No figure was presented in the original description. Later, Duszynski (1969) described oocysts of P. scelopori from a Costa Rican lizard, averaging 41 to 48 by 29 to $33 \mathrm{~mm}$, shape index 1.39; and sporocysts measuring 8 to 10 by 7 to $9 \mathrm{~mm}$, shape index 1.07 . The sporulated oocysts are oval, colourless, with no polar body but with an oocyst residuum consisting of small scattered granules.

Another coccidian parasite Polysporella genovesae n. gen., n. sp., from Galapagos Mockingbird Nesomimus parvulus was described recently. The oocysts are ellipsoidal and colorless $(43.4 \times 33 \mathrm{~mm})$ with a bilayered wall, no micropyle or polar granules and varying sized granules, contains 9-15 spheroidal or slightly subspheroidal sporocysts with 2 sporozoites in each (McQuistion
1990). The author discusses the relation between this new genus/species and two other genera: Octosporella containing 8 sporocysts with 2 sporozoites each and Hoarella containing 16 sporocysts with 2 sporozoites each (Hammond \& Long 1973). The new genus is between these two genera. The species described by McQuistion (1990) is different from the genus Pythonella described in this article which presents 16 sporocysts with 4 sporozoites in each of them.

All the 29 birds trapped in this article were from the order Passeriformes belonging to 14 different species. Two of the collected species Sclerurus scansor were both passing Isospora spp. type oocysts and in one of them, oocysts of the new Pythonella species.

The parasite described in this article represents the first record of Pythonella species in a bird. The mature oocysts have the same number (16) of sporocysts and differ in some respects from those of P. scelopori: a two layered wall instead of a single layer and slightly bigger sporocysts, although oocyst size and shape were similar in both species. $P$. bengalensis oocysts are smaller than both of the other two species. The oocysts with 16 sporocysts with 4 sporozoites each, described here, can clearly be seen by optical microscopy observations, which are reproduced in the drawing picture (Fig. 1). However, the photomicrographs do not focus clearly on all four sporozoites inside a sporocyst at the same time because the oocysts are tridimensional. Fig. $2 \mathrm{C}$ shows 3 sporozoites clearly visible and the fourth partly hidden and in Figs 2B, 2D, $2 \mathrm{E}$, at least 3 visible sporozoites can be seen, suggesting the presence of a fourth which is out of focus.

It seems unlikely that infection with P. scleruri arose following the ingestion of snake or lizard tissues by the infected bird. McQuistion (1990) suggests the possibility of a false parasitism with $P$. genovesea in the Mockingbird due to the vast range in the diet of the bird which includes insects, crabs, fruits, etc. S. scansor is fairly common on or near the ground in the humid and mountainous locality of the Atlantic Forest (Ridgely \& Tudor 1994). Like other birds from the Family Furnariidae, it usually feeds on insects and their larvae, and frequently spiders, other arthropods, molluscs, etc. (Schubart et al. 1965). The great number of sporulated oocysts observed in the faecal sample collected suggests the production of these oocysts as a final stage of the parasite inside the intestinal cells of $S$. scansor. This could not be verified, however, because of Brazilian laws protecting all wildlife.

Further observations are needed to determine the specific host of $P$. scleruri. 

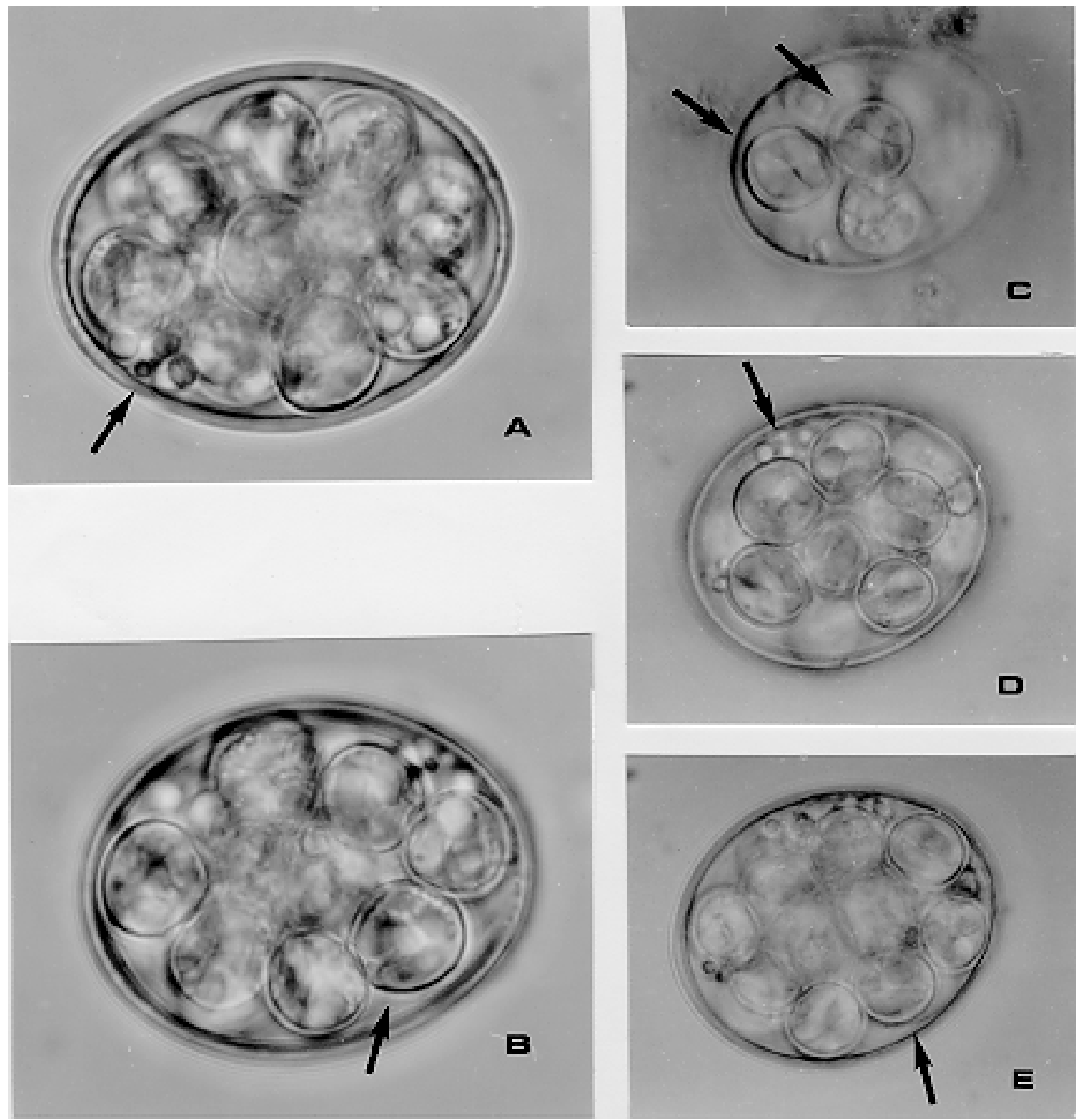

Fig. 2: sporulated oocysts of Phythonella scleruri n. sp. from Sclerurus scansor. A: 10 sporocysts and the residuum of scattered granules in focus (x 1,000); B: details of 7 sporocysts with visible sporozoites in 3 of them (x 1,000); C: a sporocyst containing 4 sporozoites, in focus (x 800); D: 10 sporocysts with at least 3 sporozoites in some of them and the residuum with scattered granules, in focus (x 800); E: 6 sporocysts with 2 or 3 visible sporozoites in some of them and the residuum of scattered granules among sporocysts (x 800).

\section{REFERENCES}

Duszynski DW 1969. Pythonella scelopori sp. n. (Protozoa: Eimeriidae) from a Costa Rican lizard. $J$ Parasitol 55: 684-685.

Hammond DM, Long PL 1973. The Coccidia Eimeria, Isospora, Toxoplasma and Related Genera, University Park Press, London, 482 pp.

McQuistion TE 1990. Polysporella genovesae n. gen., n. sp. (Apicomplexa: Eimeriidae) from the fecal contents of the Galapagos Mockingbird, Nesomimus parvulus (Passeriformes:Mimidae). Trans Am
Microsc Soc 109: 412-416.

Pellérdy LP 1974. Coccidia and Coccidiosis, 2nd ed., Verlag Paul Parey, Berlin, 959 pp.

Ray HN, Das-Gupta M 1937. On a new coccidium from the intestine of Python sp. Proc Indian Sci Congr 24: 292.

Ridgely RS, Tudor G 1994. The Birds of South America, Vol. II, The Suboscine Passerines, University of Texas Press, Austin, 814 pp.

Schubart O, Aguirre AC, Sick H 1965. Contribuição para o conhecimento da alimentação das aves brasileiras. Arq Zoolog 12: 95-249. 
